\title{
Speleoclimate dynamics in Santana Cave (PETAR, São Paulo State, Brazil): general characterization and implications for tourist management
}

\author{
Heros A. S. Lobo ${ }^{*}$, Paulo C. Boggiani², José A. J. Perinotto ${ }^{3}$ \\ ${ }^{1}$ Department of Geography, Tourism and Humanities, Campus Sorocaba - UFSCar, Sorocaba, Brazil \\ ${ }^{2}$ Departamento de Geologia Sedimentar e Ambiental, Instituto de Geociências - USP, São Paulo, Brazil \\ ${ }^{3}$ Instituto de Geociências e Ciências Exatas, Universidade Estadual Paulista - Unesp, Rio Claro, Brazil
}

\begin{abstract}
Show caves provide tourists with the opportunity to have close contact with natural underground spaces. However, visitation to these places also creates a need for management measures, mainly the definition of tourist carrying capacity. The present work describes the results of climate monitoring and atmospheric profiling performed in Santana Cave (Alto Ribeira State and Tourist Park - PETAR, Brazil) between 2008 and 2011. Based on the results, distinct preliminary zones with different levels of thermal variation were identified, which classify Santana Cave as a warm trap. Two critical points along the tourist route (Cristo and Encontro Halls) were identified where the temperature of the locality increased by $1.3^{\circ} \mathrm{C}$ when tourists were present. Air flow from the inner cave to the outside occurs during the austral summer, and the opposite flow occurs when the outside environment is colder than the air inside the cave during the austral winter. The temperature was used to establish thresholds to the tourist carrying capacity by computing the recovery time of the atmospheric conditions after the changes caused by the presence of tourists. This method suggests a maximum limit of approximately 350 visits per day to Santana Cave. The conclusion of the study is that Santana Cave has an atmosphere that is highly connected with the outside; daily variations in temperature and, to a lesser extent, in the relative humidity occur throughout the entire studied area of the cave. Therefore, the tourist carrying capacity in Santana Cave can be flexible and can be implemented based on the climate seasonality, the tourism demand and other management strategies.
\end{abstract}

Keywords: $\quad$ show caves, cave management, tourism impacts, microclimate, tourist carrying capacity

Received 4 July 2014; Revised 17 October 2014; Accepted 21 November 2014

Citation: $\quad$ Lobo H.A.S., Boggiani P.C. and Perinotto J.A.J., 2014. Speleoclimate dynamics in Santana

Cave (PETAR, São Paulo State, Brazil): general characterization and implications for tourist management. International Journal of Speleology, 44 (1), 61-73. Tampa, FL (USA) ISSN 0392-6672 http://dx.doi.org/10.5038/1827-806X.44.1.6

\section{INTRODUCTION}

Caves are the most attractive natural features of geotourism (Cigna \& Forti, 2013) and speleotourism. Some caves receive up to $1,000,000$ annual visitors, including for example show caves in Asia, Europe and North America (Cigna \& Burri, 2000). In Brazil, the number of visitors in some famous show caves, such as Maquiné, Diabo, and Lago Azul, is comparatively small, i.e., between 30,000 and 70,000 visitors per year.

Research on cave tourism is required to prevent deterioration and aid in cave management. Previous studies have been conducted to identify the natural dynamic patterns that define the limits of human activities (Graefe et al., 1990; Calaforra et al., 2003). Among other needed investigations, such as those concerning the biology of caves, the study of atmospheric dynamics provides the most useful information for use in setting limits on visitation (Calaforra et al., 2003; Cigna, 2004; de Freitas, 2010; Lobo et al., 2010). One way to understand the dynamics of the atmosphere is to measure and record air temperature and relative humidity at different points in the cave (Cigna, 2004; Luetscher \& Jeannin, 2004), specifically in areas with and without tourists (Lobo et al., 2010; Šebela \& Turk, 2014). This procedure identifies natural patterns of variation and human-induced changes (Hoyos et al., 1998; de Freitas, 2010). In some cases, more complex monitoring networks have been used that consider $\mathrm{CO}_{2}$ variations, airflow, and atmospheric pressure (e.g., Hoyos et al., 1998; Pflitsch \& Piasecki, 2003; Luetscher \& Jeannin, 2004). 
Although cave atmosphere studies provide scientific standards for the management of show caves, they do not prevent disagreements between scientists, preservationists and tourism stakeholders with purely commercial interests regarding the limits of tourist use. These conflicts are common, and management is one way to harmonize the diverse interests in caves (Lobo et al., 2013), including both tourism and conservation. Moreover, the findings of environmental studies (Cigna, 2002) and ongoing tourist demand (Šebela \& Turk, 2014) are crucial to the logical and technical basis of tourism cave management.

Based on atmospheric monitoring conducted in Santana Cave (southeastern Brazil) over three years (2009, 2010 and 2011), this study investigates the associated human impacts and shows the definition of tourist carrying capacity of this cave.

\section{STUDY AREA}

Santana Cave is located within a natural protected area (PETAR - State Tourist Park of Alto Ribeira) that is known for many caves and area of Atlantic rainforest. This location in southern São Paulo State, Iporanga Municipality, which is $340 \mathrm{~km}$ from São Paulo City (Fig. 1), has been promoted as a crescent tourist area with approximately 25,000 visitors per year.

The cave, which developed in Neoproterozoic carbonatic rocks of the Açungui Group (Faleiros \& Campanha, 2004), presents 8,373 m of known passages and galleries (Gpme, 2012), of which only approximately $480 \mathrm{~m}$ are used for tourism due to environmental restrictions.

The cave is located in the Ribeira hydrographic basin, which is characterized by a humid climate that

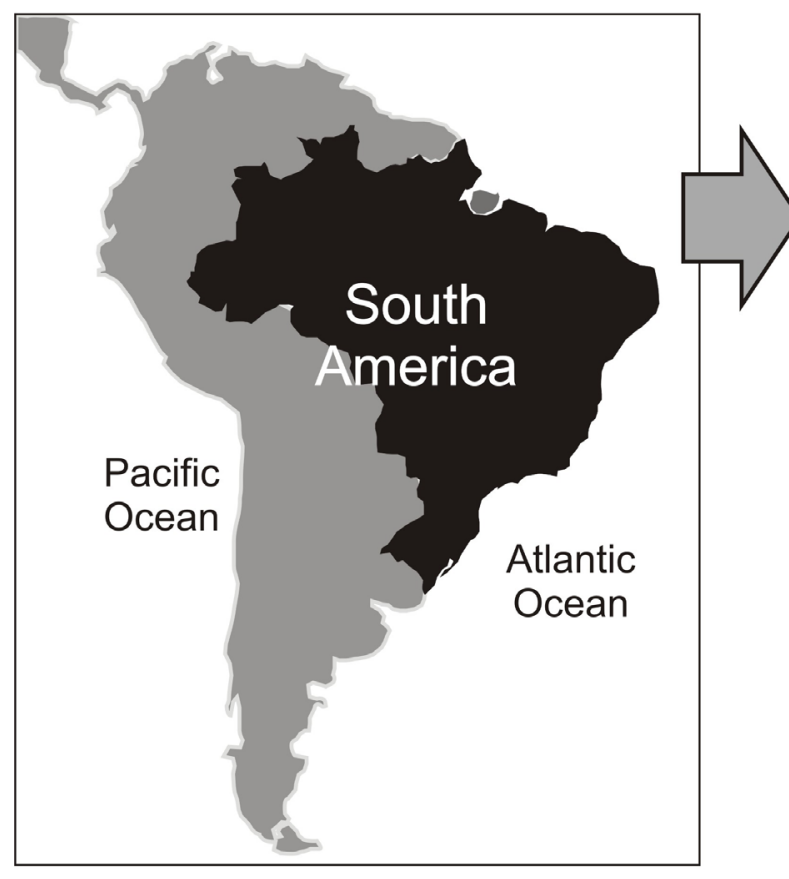

Fig. 1. Localization of Santana Cave.

is influenced by tropical and polar air masses. The relative humidity is approximately $100 \%$ throughout the year, but daily fluctuations may occur due to the local incidence of sunlight; the relative humidity can drop to $60 \%$ and then return to total saturation in the evening (Cruz Jr. et al., 2005a).

The annual average rainfall is close to $1,500 \mathrm{~mm}$ (Gutjahr \& Tarifa, 1993; Cruz Jr. et al., 2005b). The distribution of the rain is not homogeneous; approximately $33 \%$ of the annual rain occurs in the austral summer (December to February), whereas $18 \%$ of the annual rain occurs during the austral winter (June to August) (Gutjahr \& Tarifa, 1993). The long-term regional average temperature is $19^{\circ} \mathrm{C}$ to $21^{\circ} \mathrm{C}$ (Gutjahr \& Tarifa, 1993) and previous studies in Santana cave measured an average of $18.6^{\circ} \mathrm{C}$ outside the cave (Cruz Jr. et al., 2005b).

\section{METHODS}

The research consisted of monitoring the air temperature and humidity inside and outside the cave using 9 thermohygrometers with data logger Testo 175-H2 (resolution: $0.1^{\circ} \mathrm{C}$ for temperature and $0.1 \%$ for relative humidity; accuracy: $0.1^{\circ} \mathrm{C}$ for temperature and $0.3 \%$ for relative humidity) and 2 thermohygrometers with data logger and external probes Testo $177-\mathrm{H} 1$ (resolution: $0.1^{\circ} \mathrm{C}$ for temperature and $0.1 \%$ for relative humidity; accuracy: $0.2{ }^{\circ} \mathrm{C}$ for temperature and $0.5 \%$ for relative humidity).

The measurements were conducted at intervals of 20 or 30 minutes depending on the situation. The monitoring was conducted in different phases over three years $(2009$, 2010 and 2011); thus, the distributions and positions of the monitoring stations varied, and the number of instruments (stations) used varied from 6 to 11 (Fig. 2). This temporal resolution was considered satisfactory to determine the seasonality of patterns and the changes generated by visitors. Similar studies, including those by Hoyos et al. (1998), Sánchez-Moral et al. (1999), Calaforra et al. (2003), and Fernández-Cortés et al. (2006a, b), were based on less complex networks in which the number of monitoring stations varied between 2 and 6 . To complement the relatively low spatial density of the data 
collection, an atmospheric profile was developed to allow for a more complete geospatialization of the data through interpolation by following the examples of Fernández-
Cortés et al. (2006b) and Milanolo \& Gabrovšek (2009). For the atmospheric profiling of Santana Cave, 75 sampling points were used (Fig. 2).

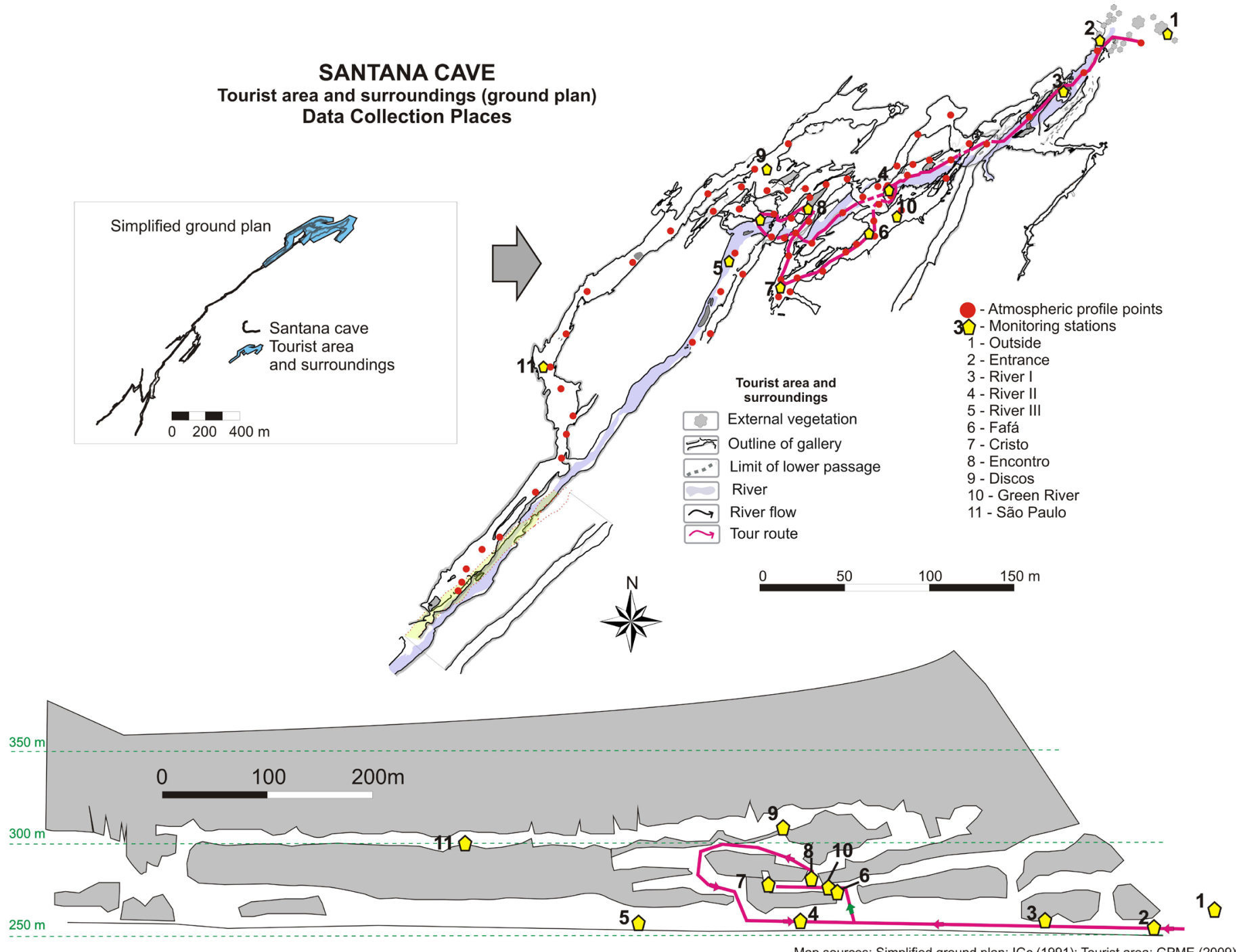

Fig. 2. Profile points and monitoring stations in Santana Cave.

The collected data were analyzed by descriptive statistics and statistical procedures for time series analysis that are widely used in hydrogeology (e.g., Mangin et al., 1999) and climatology (e.g., Calaforra et al., 2003; Fernández-Cortés et al., 2006a, b). The data on the atmospheric profiles were analyzed using geostatistical procedures and were interpolated according to three algorithms: linear triangulation, trend surface (2nd to 5th order), and ordinary kriging. The analysis was applied to the temperature and relative humidity data, but only the temperature results are presented in this article; the relative humidity had a low variability after the initial $100 \mathrm{~m}$ of the cave in which all of the obtained values were constant and approximately $99.9 \%$. In the case of air temperature, the second order of the trend offered the best adjustment of the results.

After data collection and analysis, the second phase consisted of establishing the tourist carrying capacity of Santana Cave based on the atmospheric studies. To this end, a new method was developed by Lobo (2011, 2014) based on the recovery time of an atmospheric variable. Similar methods were being used in Spanish show caves (Calaforra et al., 2011; Guirado et al., 2014). In Santana Cave, the air temperature was selected as atmospheric variable. This parameter, along with $\mathrm{CO}_{2}$, provides the best evidence of human presence in Santana Cave (Lobo, 2013).

The CCSC (Carrying Capacity of Santana Cave) method is based on fundamental climatic data to provide specific answers regarding the daily limits of cave usage. Basically, the maximum accepted recovery time of a specific parameter must be shorter than the interval between the end of the visitation one day and the beginning of the visitation the next day. Although there is no defined limit for acceptable impacts on Santana Cave, a cautious position was assumed to ensure that thermal accumulation would be avoided, as reported by Song et al. (2000) in a Chinese show cave. The recovery time limit is the conceptual baseline for the CCSC and is supported by public policies of natural protected areas of Brazil. The developed equations are based on simple management requirements, such as the times of tour routes, the maximum number of people in each group, the interval between groups of visitors, and the maximum acceptable duration of visits 
at critical points in Santana Cave, which is likely the most important variable to avoid generating a negative impact that exceeds the maximum recovery time.

\section{RESULTS AND DISCUSSION}

\section{Speleoclimate dynamics}

The longest continuous data series (annual) of temperature is shown in Fig. 3, and the relative humidity of three monitoring stations (Outside, Entrance and
River I) is shown in Fig. 4. The relative humidity at the various stations inside the cave was constant and approximately 99.9\%; the only exceptions were values between $96 \%$ and $99.9 \%$ (average of $99.8 \%$ ) recorded at the River I station during the relatively drier months from June to August 2010.

Outside the cave, the maximum temperature was $32.9^{\circ} \mathrm{C}$ (February 2010) in the rainy season (summer), and the minimum temperature was $13.8^{\circ} \mathrm{C}$ (September 2009) in the dry months (winter). In the less rainy

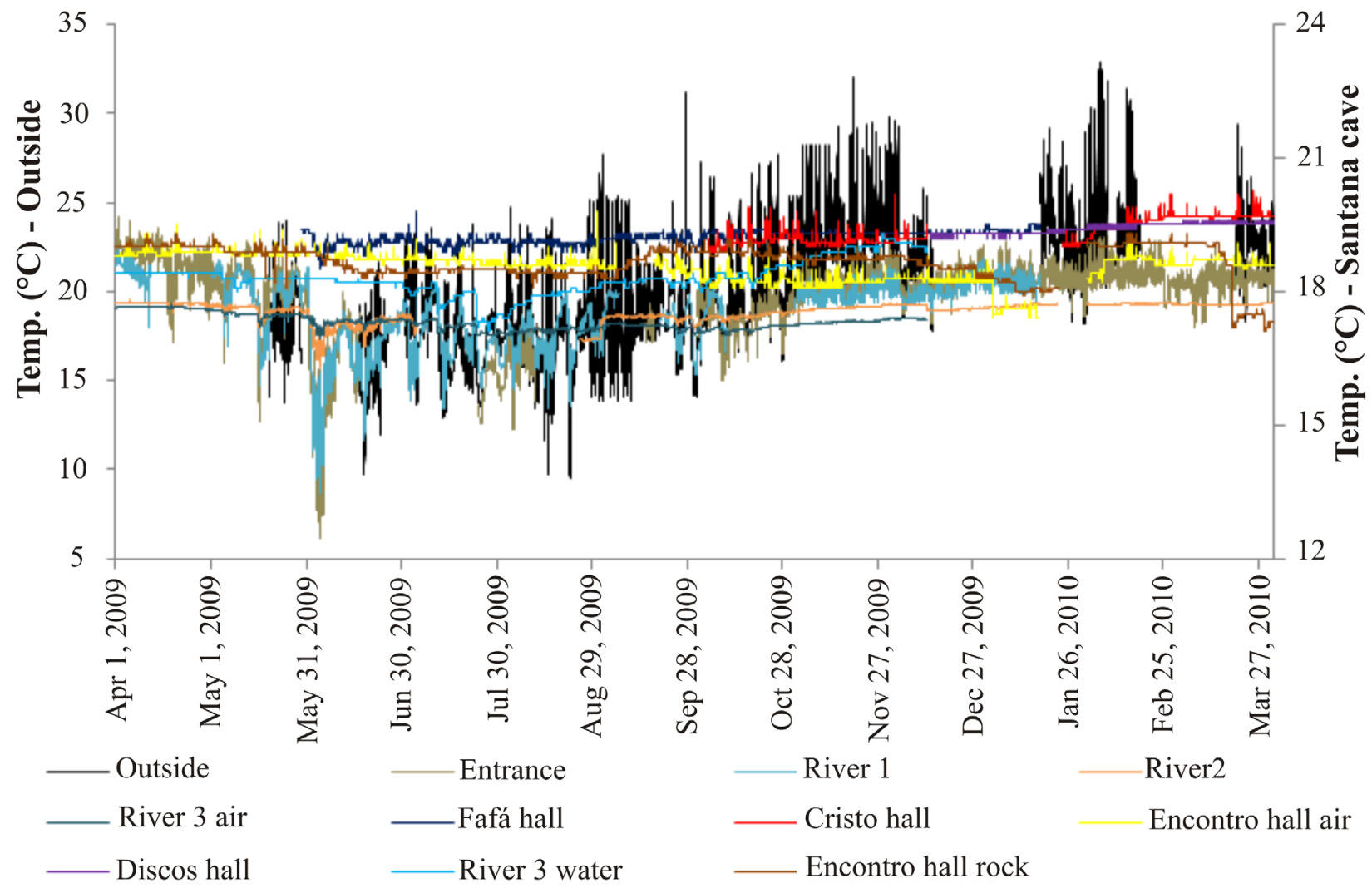

Fig. 3. Annual results of temperature monitoring of Santana Cave (2009-2010).

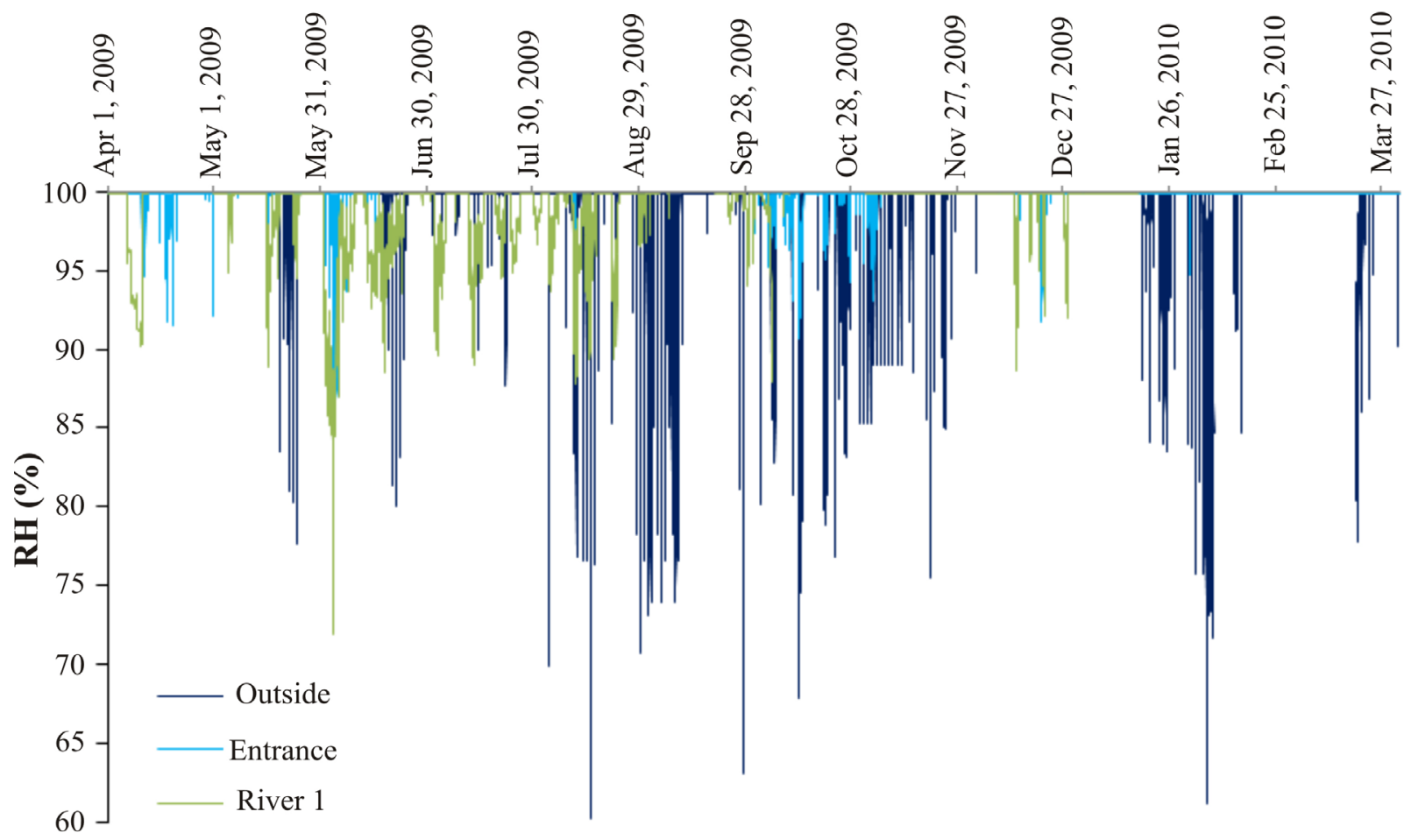

Fig. 4. Annual period of relative humidity monitoring at three stations (Outside, Entrance and River I) of Santana Cave (2009-2010). 
season, the maximum temperature was $29.4^{\circ} \mathrm{C}$ (March 2010) and the minimum temperature was $6.1^{\circ} \mathrm{C}$ (June/2009). Therefore, a major difference was observed in the average temperature: $21.3^{\circ} \mathrm{C}$ in the rainy season and $18.0^{\circ} \mathrm{C}$ in the relatively drier season. The average relative humidity was $98.9 \%$, the maximum was $99.9 \%$, and the minimum was $60.2 \%$.

The minimum temperature recorded in the cave was $17.3^{\circ} \mathrm{C}$ at the River III station, which did not experience visitor interference. The maximum temperature was $19.3^{\circ} \mathrm{C}$, and the annual average was $18.2^{\circ} \mathrm{C}$ at the same station. The average difference found between the
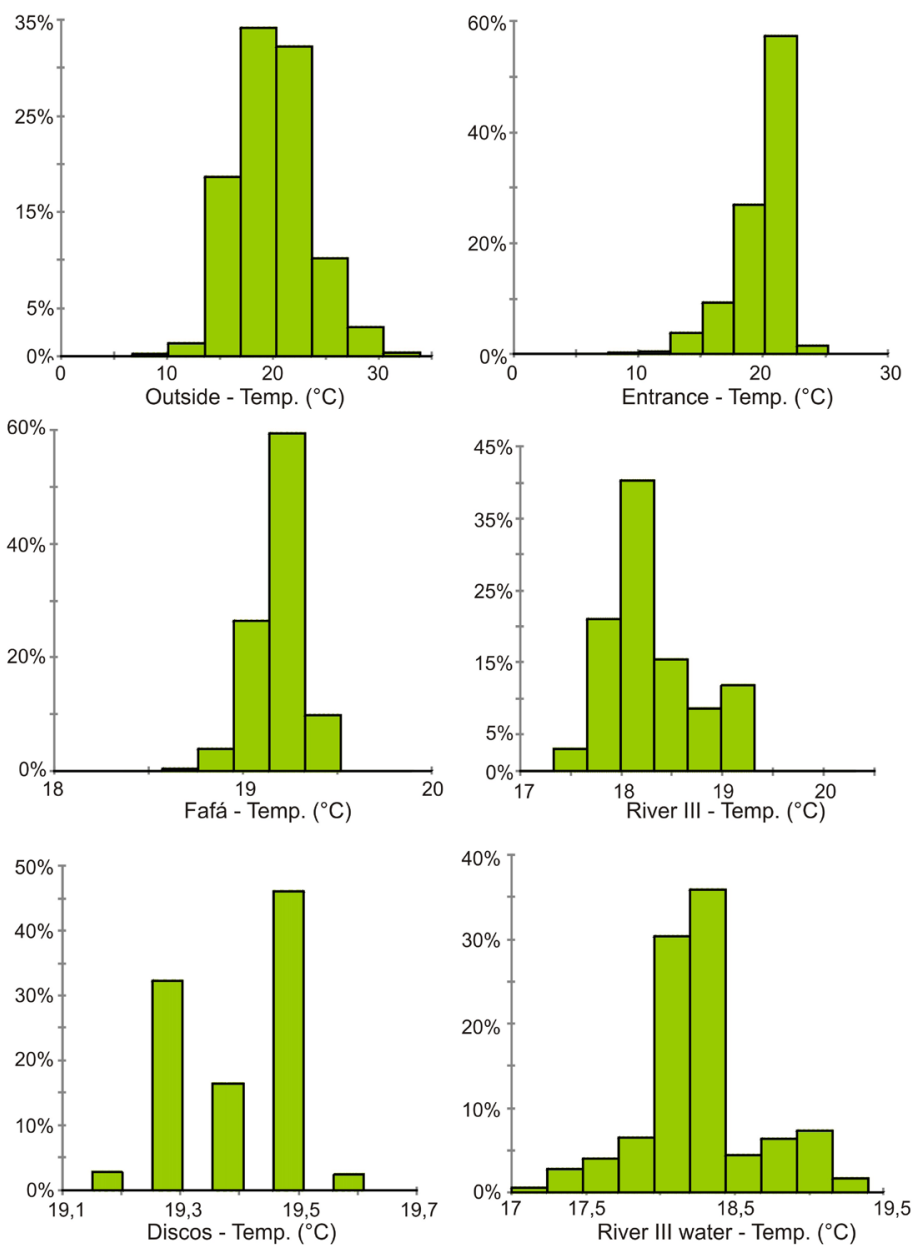

rainy and relatively drier periods was less than $0.5^{\circ} \mathrm{C}$. The relative humidity in the interior of the cave near the River II station was $99.9 \%$ over the entire research period. The general patterns for each data sequence of the temperature are shown in the histograms of Fig. 5. The histograms provide a visual representation of the similarity among the Entrance, River I, River II, and Fafá stations; to a lesser extent, Encontro (air) and Encontro (rock) are similar to each other. However, the Outside and River III (air and water) stations are also similar. The Cristo and Discos stations present irregular patterns compared with the other stations.
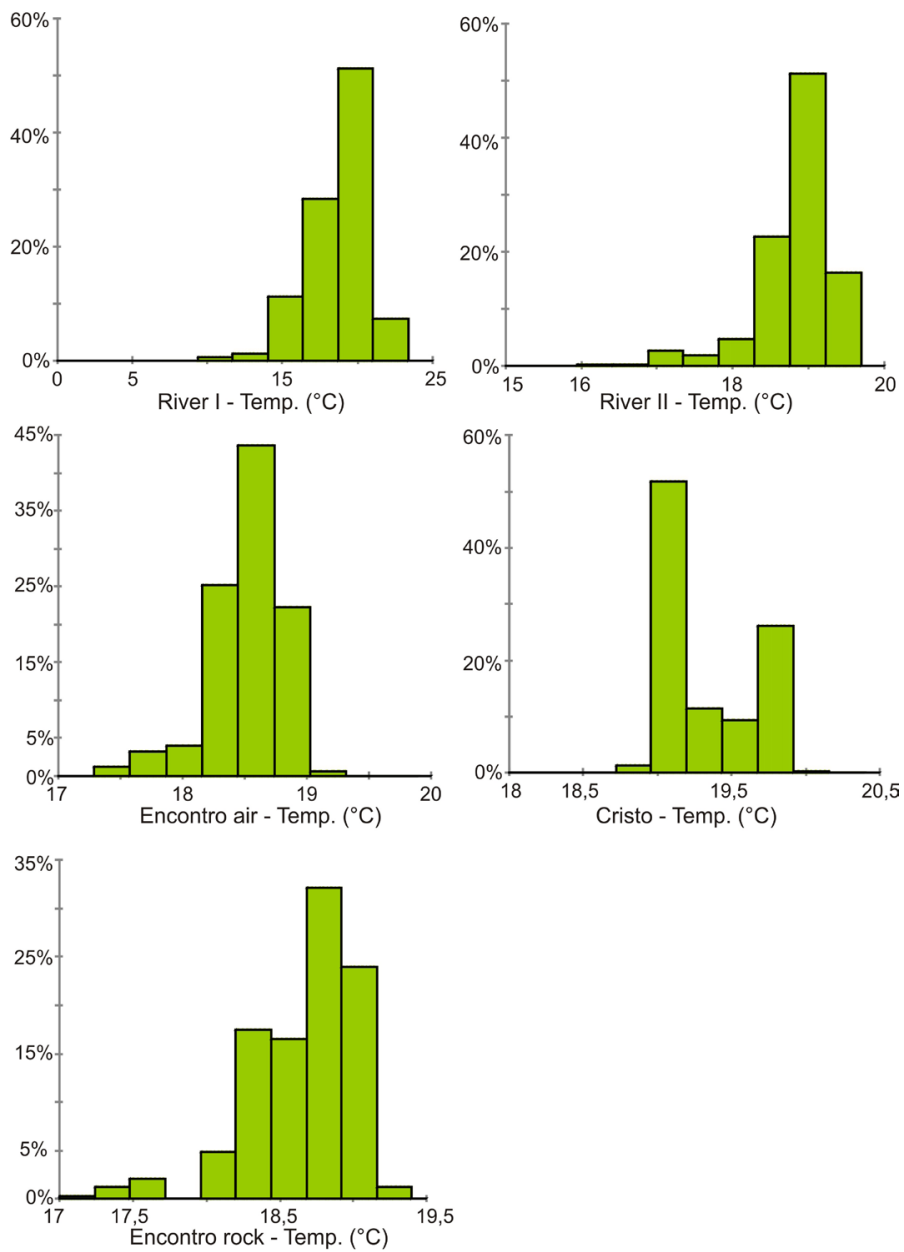

Fig. 5. Histograms of the relative frequencies of air temperature sequences at different stations (2009-2010).

To verify the visual differences and similarities, correlation tests between the variables were performed. The Cross-correlation coefficients (Tab. 1) confirm the strong connections between the temperature series. The influence of the external microclimate is greater at the Entrance (0.835), River I (0.589), River II (0.534), Fafá (0.504) and River III_air (0.504) stations. The Encontro station did not present a great correlation with the external environment (0.320).

The majority of the analyzed stations reflect the variations of the outside climate within a matter of hours. The autocorrelation patterns (Fig. 6) demonstrate the differences in the datasets and help determine preliminary zones based on temperature variability patterns.

Although the series of temperature correlograms (Fig. 6) present different time extensions, it is possible to compare their variations. The Outside station presents the fastest decay, followed by the correlograms of the Entrance, Green River, and River III air stations. The diurnal variability is apparent in the four correlograms, especially at the Outside and Entrance stations. However, the Green River station has a small intensity. The Outside and Entrance stations are very similar in terms of their variability range and velocity of decline.

Based on the collected information, Santana Cave was qualitatively classified as a warm trap (Lobo, 2011; Lobo et al., 2014). The physical structure of the cave, which includes an extensive network of galleries above the base level, forces the coldest air masses found in the interior of the cave to flow toward the outside during the warmest periods (cf. Cigna, 2004). This phenomenon occurs on a diurnal cycle and seasonally due to thermodynamic equilibrium. The flow reverses when the air outside is colder than 
Table 1. Cross-correlation coefficients, time lags, and index correlations between the external and internal stations (2009-2010).

\begin{tabular}{|l|l|r|}
\hline \multicolumn{1}{|c|}{ Outside Station $\mathbf{x}$} & \multicolumn{1}{c|}{ Variable } & \multicolumn{1}{c|}{ Value } \\
\hline \multirow{2}{*}{ Entrance } & Correlation (zero interval) & 0.835 \\
\cline { 2 - 3 } & Lag (hours) & $(0.835) 0 \mathrm{~h}$ \\
\hline \multirow{2}{*}{ River I } & Correlation (zero interval) & 0.589 \\
\cline { 2 - 3 } & Lag (hours) & $(0.597) 2 \mathrm{~h}$ \\
\hline \multirow{2}{*}{ River II } & Correlation (zero interval) & 0.534 \\
\cline { 2 - 3 } & Lag (hours) & $(0.536) 1 \mathrm{~h}$ \\
\hline \multirow{2}{*}{ River III air } & Correlation (zero interval) & 0.504 \\
\cline { 2 - 3 } & Lag (hours) & $0.545) 435 \mathrm{~h}$ \\
\hline \multirow{2}{*}{ Fafá } & Correlation (zero interval) & 0.504 \\
\cline { 2 - 3 } & Lag (hours) & $(0.510) 4 \mathrm{~h}$ \\
\hline \multirow{2}{*}{ Cristo } & Correlation (zero interval) & 0.033 \\
\cline { 2 - 3 } & Lag (hours) & $(0.285) 533 \mathrm{~h}$ \\
\hline \multirow{2}{*}{ Encontro air } & Correlation (zero interval) & 0.320 \\
\cline { 2 - 3 } & Lag (hours) & $(0.510) 1872 \mathrm{~h}$ \\
\hline
\end{tabular}

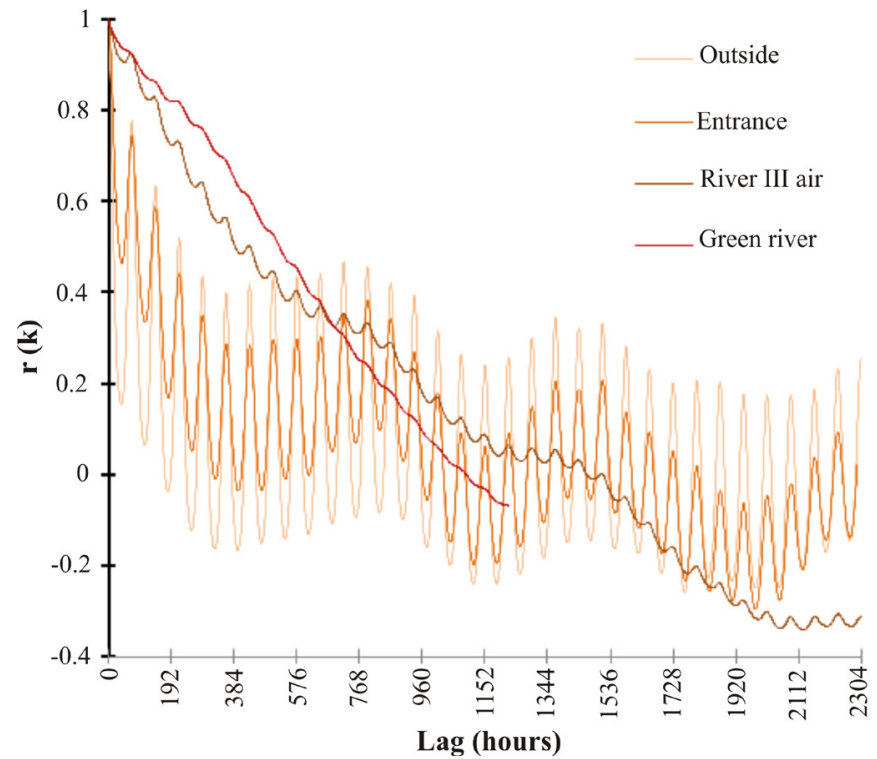

Fig. 6. Comparative correlogram of air temperature at four monitoring stations in Santana Cave.

the air inside the cave. Thus, the air moves to the interior of the cave, where the circulation is limited by a hot air pocket in the upper and most confined galleries of the system. Due to small passages (see details in Fig. 9) and the paleo-resurgence near the present resurgence area of the Roncador River, a small peripheral air circulation is generated in accordance with the principles of thermoregulation.

The hot air masses confined in the upper galleries also exhibit dynamic behavior in terms of atmospheric exchanges. These exchanges can occur due to thermal conductivity, this direct air flow is not detected by the monitoring instruments. This condition emphasizes the speleoclimatologic research conducted by Cigna \&
Forti (1986), Pflitsch \& Piasecki (2003) and Luetscher $\&$ Jeannin (2004); specifically, due to various factors, the speleoclimate in the inner part of a cave is not constant or static. Although the modifications occur at a small scale, in galleries and chambers, they always occur and are critical to comprehending speleoclimate dynamics, accumulation mechanisms, and "cave breathing", at a large scale (cave systems). To thoroughly investigate this dynamic, two other data periods were selected. One period was in the cold season, and the other period was in the warm season; the data from the stations of the river gallery and the upper galleries were compared with the data from the Outside station (Tab. 2).

The coefficients shown in Tab. 2 for the cold season reveal two major correlations in the data: Outside x River I (0.638) and Encontro x River III air (0.939).

The selected period in the warm season included the days between 10 and 18 February, 2010. The coefficients of correlation among the stations in this period are shown in Tab. 3.

Pearson's $r$ confirms a major positive correlation between the Outside station and the Entrance (0.885), Encontro (0.663) and Cristo stations (0.611) and a low correlation between the Outside station and the River II (0.188) and Discos stations (0.172). Moreover, the Encontro and Cristo stations are highly correlated (0.738).

The interpretation of the seasonal data in the cold and warm periods of the year highlighted the airflow in Santana Cave. Thus, the complete series were divided into the coldest and warmest months so that descriptive statistical analysis could be used. The maximum and minimum for every month are relevant to the present analysis (Fig. 7).

Table 2. Matrix of proximity (Pearson's r) between the selected monitoring stations - July 2009.

\begin{tabular}{rrrrrrr}
\hline & \multicolumn{1}{c}{ Outside } & \multicolumn{1}{c}{ River I } & \multicolumn{1}{c}{ Fafá } & Encontro & River III air \\
\hline Outside & 1 & 0.638 & 0.302 & 0.358 & 0.308 \\
& River I & 1 & 0.142 & 0.446 & 0.433 \\
& & Fafán & 1 & 0.006 & -0.094 \\
& & & Encontro & 1 & 0.939 \\
& & & & River III air & 1 \\
\cline { 3 - 6 }
\end{tabular}


Table 3. Proximity matrix (Pearson's r) among the selected monitoring stations - February 2010.

\begin{tabular}{|c|c|c|c|c|c|c|}
\hline & Outside & Entrance & River II & Encontro & Cristo & Discos \\
\hline \multirow[t]{6}{*}{ Outside } & 1 & 0.885 & 0.188 & 0.663 & 0.611 & 0.172 \\
\hline & Entrance & 1 & 0.111 & 0.562 & 0.538 & 0.122 \\
\hline & & River II & 1 & 0.289 & 0.429 & 0.334 \\
\hline & & & Encontro & 1 & 0.738 & 0.232 \\
\hline & & & & Cristo & 1 & 0.252 \\
\hline & & & & & Discos & 1 \\
\hline
\end{tabular}

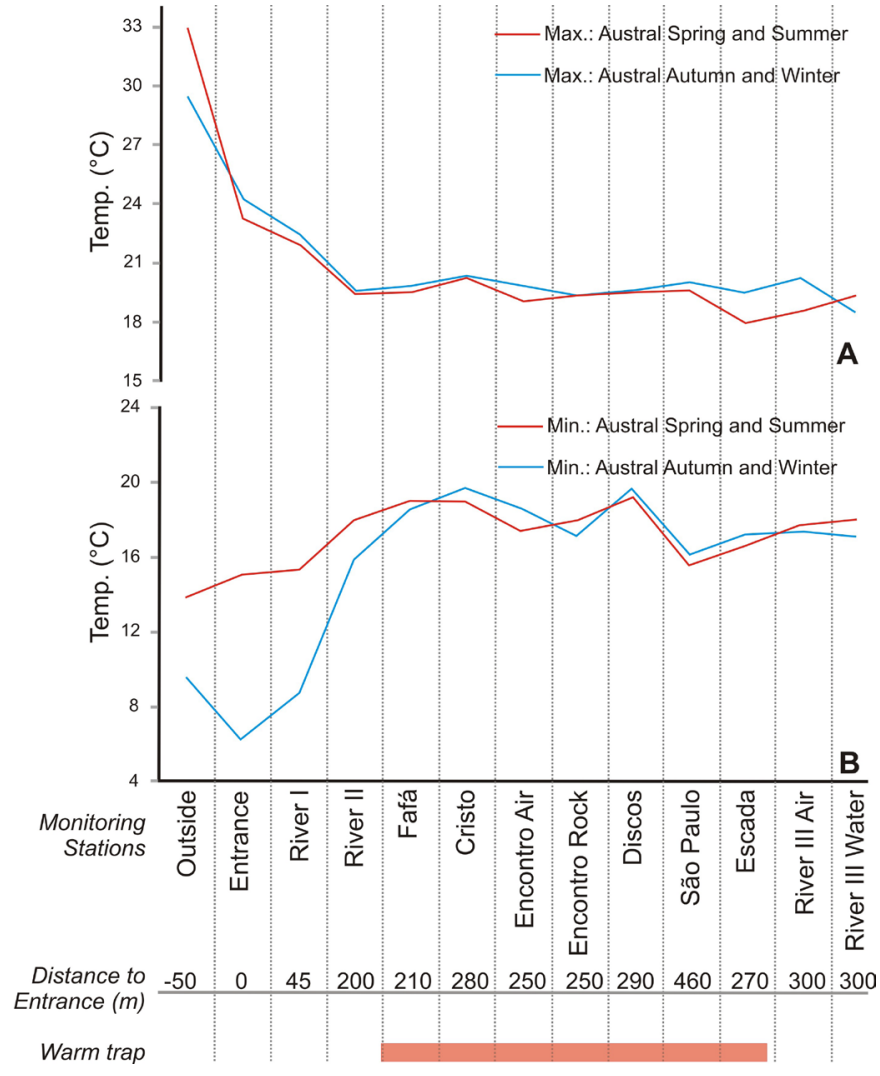

Fig. 7. Maximum (A) and minimum (B) temperature at each monitoring station during the cold and warm seasons (2009-2010). Modified from Lobo et al. (2014).

The data shown in Fig. 7 demonstrate the difference of temperature in Santana Cave during the warm and cold periods of the year and are consistent with the previous interpretation of the cave as a warm trap. In the coldest period (March August), the maximum temperature recorded at each station in the interior of the cave is higher than the maximum recorded in the warm period (September - February); the minimum temperatures are lower in the warm period (September - February) at the stations inside the cave. Furthermore, regarding the minimum temperatures, the external climate impacts the temperatures at the Entrance, River I, River II, Fafá, and River III (air) stations. Thus, preliminary limits for the higher intensity of direct atmospheric exchange between the external and internal environments are determined.

Considering the warmest period, the correlation coefficient and supporting material can be used as timespace profiles for air temperature. In Santana Cave, the air temperature exhibits a cumulative potential toward the interior of the cave and in the upper galleries. This pattern is more evident in the temperature profile of April 2010 (Fig. 7A) and usually occurs in austral autumn (march - may), but the lowest temperature, approximately $18^{\circ} \mathrm{C}$, had already occurred in the year 2010. Notably, the thermal accumulation in the Green River station and surroundings occurred in a confined and upper gallery that is close to the external environment. The profile of January/2011 (Fig. 7B), i.e., austral summer, also exhibited thermal accumulation in the upper galleries - Cristo, Discos, Aranhas, São Paulo, and São Jorge Halls.

Moreover, the interpretation of the obtained data, together with the air flow measurements, is displayed in Fig. 8. This interpretation is based on the patterns of temperature presented in the histograms (Fig. 5), the cross-correlation coefficients (Tab. 1), the correlograms at four monitoring stations (Fig. 6) and the correlation coefficient $r$ (Tab. 3).

Based on Fig. 8, a model of the atmospheric circulation proposed for the research area of Santana Cave is summarized in Fig. 9. The model focused not only on the warm trap but also on the approximate limits of the possible climate zones of the cave. Santana Cave presents various levels related to the air temperature variation. Thus, the thermal speleoclimate zones are confirmed by the previous analysis of Lobo et al. (2009), in which the air temperature was determined in a small-scale study. The transitional zone varies simultaneously with the temperature variation of the external environment. This variation becomes less intense in the internal typical zone and in the low thermal amplitude zones; thus, a more stable area is apparent. This phenomenon is observed in Flores Hall, where minimum variations occur on a weekly basis. Fig. 9 also highlights the existence of physical barriers in the environment, which were interpreted as key factors to establishing limits for these zones. However, other aspects, such as the distance to the external access, the physical formation of the environment, the presence of water and the dimensions of the galleries are also important in the thermal stratification of the cave's atmosphere (cf. Poulson \& White, 1969; Luetscher \& Jeannin, 2004).

A physical barrier may cause the variations of air humidity in Santana Cave in the distinct zones; the transitional zone presented a large humidity variation from $\sim 71 \%$ to $99.9 \%$. The interpretation is that the restricted gallery of the Roncador River and the juxtaposition of a huge conjunct of speleothems (stalactites and flowstones) may be the main factors that limit the influence of the outside microclimate on the inner parts of Santana Cave. After this point, only at River II (the beginning of the Internal-Typical zone), low variations of relative humidity were registered. 


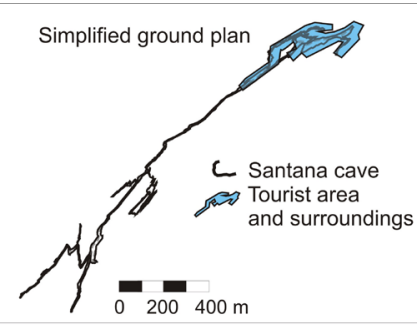

\section{Tourist area and surroundings (ground plan)} Maps of Isothermal Zones

A - April 10, 2010

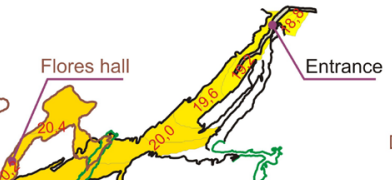

B - January 1, 2011

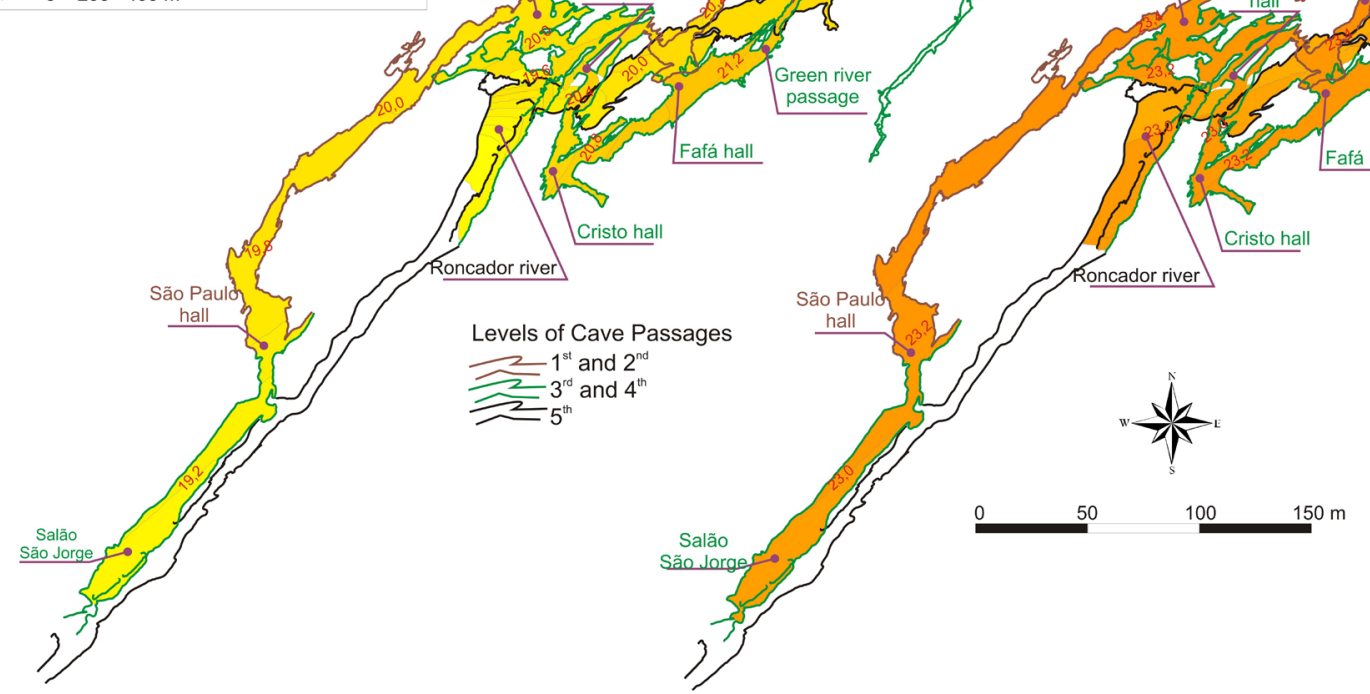

Fig. 8. Trend surface (second order) of thermal profiles of Santana Cave. Modified from Lobo (2013).

Conceptual qualitative model of air flow of the final part of Santana Cave (profile view)

Austral summer (rainy season in the PETAR area)

(As well as in warm periods of the winter)
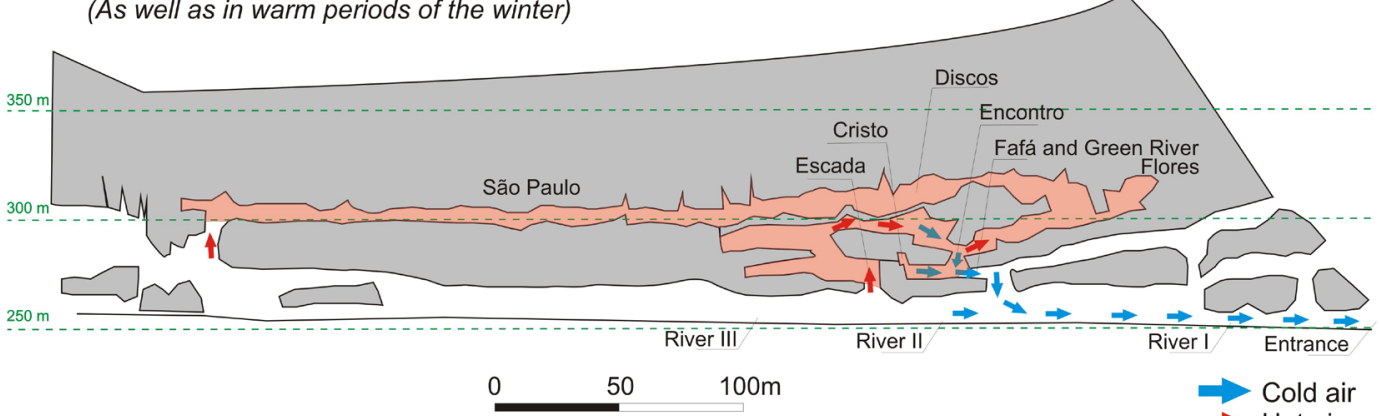

trance

in the PETAR area) (As well as in cold periods of the summer)

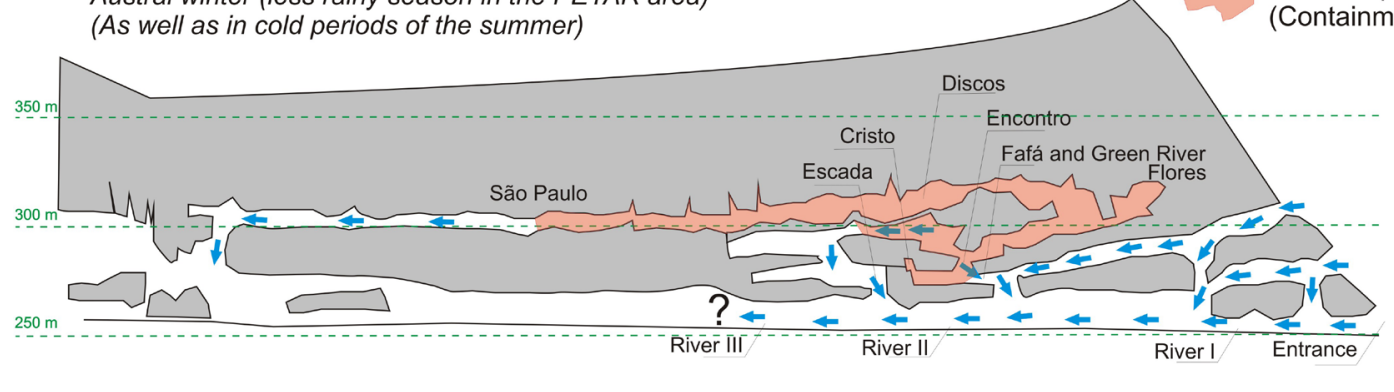

First approach for speleoclimate zones (thermal) of the final part of Santana Cave (Profile view)

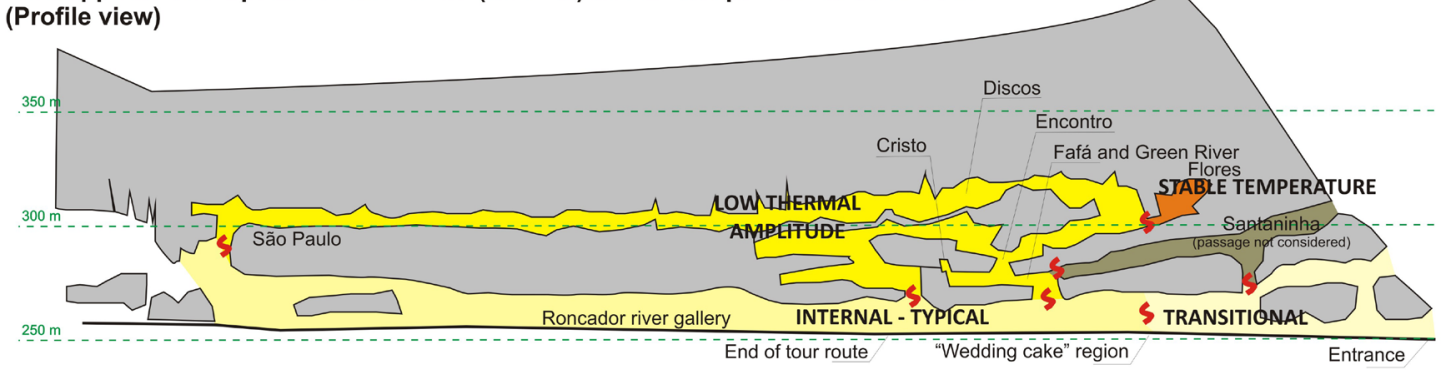

CLIMATE ZONE (after Lobo et al., 2009)

$\$$ Restrictions to air flow

Fig. 9. Conceptual model of air circulation in a partial longitudinal section of Santana Cave, which is characterized as a warm trap (Lobo et al., 2014), and the climate zones according to Lobo et al. (2009). 
Impacts on speleoclimate and tourist carrying capacity

The main problem of tourism in a cave is the alteration of the physical-chemical conditions of the inner atmosphere. In some fragile caves, such as Lascaux Cave in France (Bastian \& Alabouvette, 2009) and the geode of Pulpí, Spain (Fernández-Cortés et al., 2006a), tourist activity is completely prohibited. At Lascaux Cave, tourism is prohibited to protect the rock paintings, whereas at the geode of Pulpi, tourism is banned to avoid the deterioration of the unstable minerals in this very small cave.

All environmental parameters are important to understand to protect a cave and alleviate the effects of tourism, but there are limitations to complete analyses, and investigations must prioritize the speleoclimate data (Hoyos et al., 1998, Sánchez-Moral et al., 1999, Calaforra et al., 2003, Fernández-Cortés et al., 2006a).

In the present study of Santana Cave, the analysis of the impact on the speleoclimate was concentrated on the air temperature because the relative humidity was not influenced by tourist groups. A direct correlation with visits was conducted, and a daily visitor limit was established. However, this approach to evaluate the tourist carrying capacity of an environment provides restricted results because the dynamics of high-level energy environments, such as those in Santana Cave, were neglected. In the case presented here, extreme environmental fragilities, such as rock paintings and rare and unstable minerals, are absent.

Thus, the daily thermal amplitudes at the Cristo and Encontro stations (in the halls where the tourist groups spend more time) were calculated for the period from 23 August 2009, to 1 January 2010. Additionally, the available daily visits (tourist and tour guides) data were considered (Fig. 10).

Two monitoring stations were located in relatively small galleries where the visitors spend more time - the Cristo and Encontro stations. The comparison between the thermal amplitudes (highest temperature - lowest temperature) and the number of visits per day is shown in Fig. 10.

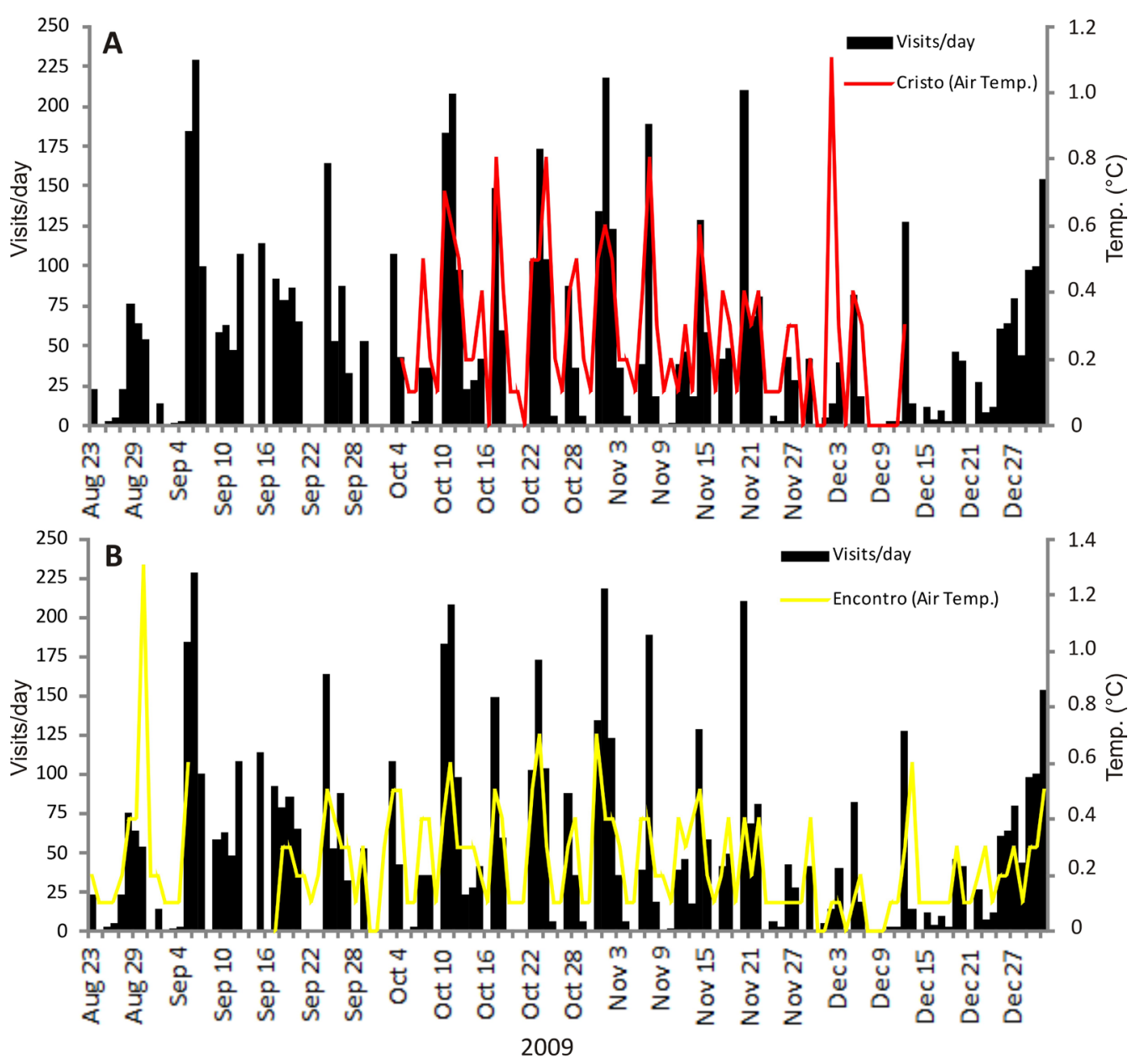

Fig. 10. Daily air temperature amplitude at the Cristo station (A) and Encontro station (B).

The predominant daily amplitude without visits in Cristo and Encontro halls was $0.1^{\circ} \mathrm{C}$. The tourist groups generated maximum daily amplitudes of $1.1^{\circ} \mathrm{C}$ (Cristo) and $1.3^{\circ} \mathrm{C}$ (Encontro), although most of the variations were $0.1-0.5^{\circ} \mathrm{C}$ (Cristo) and $0.1-0.4^{\circ} \mathrm{C}$ (Encontro). These values were generated by groups with variable numbers of visitors, using just flashlights as light sources. The most of flashlights used in Santana Cave were of LED technology, which waste less energy as heat (Cigna, 2011). Thus, the main heat source was the human body, which releases between $82 \mathrm{~W}$ and $160 \mathrm{~W}$, according to Villar et al. (1984). In Cristo hall, for example, 2 visitors increased the daily temperature amplitude to $0.2^{\circ} \mathrm{C}$, the presence of 12 visitors caused an increase of $0.3^{\circ} \mathrm{C}$, and 8 visitors caused an increase of $0.4^{\circ} \mathrm{C}$. In Encontro hall, the presence of 2 visitors generated a thermal amplitude of $0.1^{\circ} \mathrm{C}$, and 18 visitors increased this value to $0.4^{\circ} \mathrm{C}$. 
In this case, two approaches could be considered to define the carrying capacity. The first approach is related to the anthropogenic variation, which should not exceed the natural variations.

Considering that tourism visits must be conducted without modifying the natural dynamics (Hoyos et al., 1998; Calaforra et al., 2003), the temperature may be a critical factor with which to measure human modifications of speleoclimate. In Santana Cave, in an extreme case, the visits to Cristo Hall would be limited to only 1 person considering that the presence of 2 visitors generates a $0.2^{\circ} \mathrm{C}$ temperature increase. However, the limit in Encontro Hall was 13 visitors because 14 visitors caused an increase greater than $0.1^{\circ} \mathrm{C}$, which is the typical increase.

However, 92 visitors on the same day (16 September 2009) did not alter the air temperature in Encontro Hall (Fig. 10B). Thus, this assumption cannot be applied to Santana Cave, where the dynamics of the atmosphere did not respond as expected due to the nonlinear data. In another example, a group of 14 visitors generated a daily amplitude of $1.1^{\circ} \mathrm{C}$ in Cristo Hall (2 December 2009 - Fig. 10A). Meanwhile, 210 visitors divided into various groups generated an amplitude of $0.4^{\circ} \mathrm{C}$. After many tests, it was determined that the increase in temperature was directly connected to the length of time tourists spent in the halls and not to the number of visitors in each group. This situation was observed at the Cristo and Encontro stations, where the guides spend more time during the visit and, consequently, the temperature increases.

A second approach to define the carrying capacity is to consider modern management principles, such as those presented by Graefe et al. (1990) in his framework entitled "Visitor Impact Management," which was developed for trails and used in cave management in Australia (Hamilton-Smith, 1997) and New Zealand (de Freitas, 2010). This research is based on the understanding that anthropogenic activity cannot occur without altering the environment. Based on this assumption, the study aimed to find alterations due to human presence that do not persist in the environment over long time intervals. Timeextensive impacts are not acceptable because all the consequences of alterations of a specific environmental parameter are not known.

A new methodology that is based on the data presented in this article is proposed for determining the carrying capacity of Santana Cave (CCSC - Lobo, 2011, 2014); the method is divided into three steps: I) identify and list the tourist and educational attractions and access points to delimit the walking trail and interpretative program; II) design the ideal tourist scenario; III) Obtaining a time limit based on environmental critical factors as a threshold for CCSC.

The proposed method to identify the carrying capacity (Lobo, 2014) depends on the specific characteristics of each cave, and similar procedures were carried out by Pulido-Bosch et al. (1997) at cave of the Marvels, Spain. In the case of Santana Cave, the durations for which the tourist groups remain at the two identified points inside the cave, i.e., Cristo and Encontro stations, are important. The main factor that determined the carrying capacity of Santana Cave was the time that the tourist groups remained in the Cristo and Encontro Halls. Based on this finding, it was not relevant to determine an exact number of persons/groups that affected the atmospheric parameters. Cristo and Encontro Halls are the main bottlenecks of the walking trail of Santana Cave, and the time spent at these locations during the guided tour was identified as the principal factor of the air temperature changes. This time interval was related to the time the atmosphere needed to return to its steady state on a daily basis, following the Brazilian principles of precaution (Conama, 2004) and also considering the number of visitors per group and the time between groups without extrapolating the recovery limits of the critical factor, the air temperature (Lobo, 2011). This limit is considered a function of the recovery time and the time available to recover. In this case, the limit was considered as the time interval between the end of the visits one day and the start of the visits the next day to avoid the impacts described by Song et al. (2000). The application of the method in Santana Cave resulted in a CCSC of 378 visits per day (Lobo, 2014).

\section{Recommendations for management issues of Santana Cave}

Defining the number of visits per day is necessary for the public managers of Santana Cave to improve the tourist flow and, consequently, PETAR and the surrounding communities. Many local people economically depend on cave tourism in the park, where Santana Cave is the main attraction. Currently, the proposed maximum limit of visits to Santana Cave is 117 visits/day, including the guides. This limit was suggested in the study by Lobo (2008), which is based on the Cifuentes (1992) method of carrying capacity. This method was previously used in cave management in Brazil (e.g., Boggiani et al., 2007) and other countries (e.g., Nghi et al., 2007). The use of this method was criticized by Delgado (2007) and Lobo et al. (2010) due to two problems: the overlap of restrictions that are derived from environmental and social studies and the excessive limitation of tourist use without a proven cause and effect relationship.

The relatively low number of visits generates many problems in the region considering that the tourist influx is concentrated on weekends and holidays. To help mitigate this problem, the size of tourist groups determined in the management plan of Santana Cave (Fundação Florestal \& Ekos Brasil, 2010), which has not yet been implemented, was combined with the carrying capacity obtained herein. In the management plan, the tourist groups include 24 people on business days (i.e., to accommodate school groups) and 18 people on the weekends and holidays. Thus, the carrying capacity corresponds to a maximum of 378 visits per day on weekends and holidays (21 groups). The entrance interval between these groups can be as short as 20 minutes. During weekdays, the carrying capacity can be 336 visits per day (14 groups), and the entrance interval between the groups is approximately 30 minutes (Lobo, 2014).

The proposed numbers need to be tested and monitored to prove their efficacy so that adjustments 
can be made according to the options identified by the cave managers. One fundamental aspect that can be considered is the present annual average number of visits to Santana Cave, which is close to 80 tourists per day (except on Mondays, when PETAR is closed), and fewer than 35,000 visits/year. Obviously, there is an enormous discrepancy between the actual visitation and the possible visitation in this case. However, this difference can be attenuated if the carrying capacity on weekends and holidays is increased from 117 to approximately 350 visits/day. Considering that most of the visitors travel to the region on these days, modifying the limits is fundamental to improving the use of Santana Cave and would benefit the local inhabitants.

Finally, it is important to note that the atmosphere of Santana Cave is highly related to the outside conditions according to the daily variations of temperature and relative humidity in the part of the cave studied. This finding must be considered in the establishment of future methodologies, results, and conclusions for comparisons with those of this research. Likewise, it is important to remember that the external microclimate presents special features that should be taken into account. The atmosphere in the area surrounding the cave is influenced by the presence of steep hollows in the bottom of the valley (cockpit karst) and the thick vegetation of the Atlantic rainforest. Additional factors, such as the existence of an active watercourse - the Roncador River, for example - or even the thickness of rock cover, are relevant to future studies. Therefore, the tourist carrying capacity in caves with these conditions should be flexible and can be improved for the professional management of cave tourism.

\section{CONCLUSIONS}

The investigated atmospheric parameters demonstrated the importance of the temporal extension and density of the sample points not only in hygrothermal monitoring but also in determining atmospheric profiles. The atmospheric profiles can possibly identify the critical zones in the current tourist route. The identified environmental zones have a strong spatial component in all levels of the galleries; the zones are influenced by the Roncador River, the thickness of the rock layer and the horizontal stratification corresponding to the external and vertical environments. The environmental monitoring data contributed to the development of a general model of the atmospheric circulation in Santana Cave; the model demonstrated the thermal cumulative pattern in relation to the upper galleries (hot trap model). The air-trapping cell has a variable size that is more extensive in austral summer (December to February) and on warm days and smaller in austral winter (June to August) and on cold days; thus, air cycling by degasification occurs in the cave. The thermal profile calls special attention to the galleries of the Green River, Discos-São Paulo, and Flores Hall, and the monitoring highlights the importance of Cristo and Encontro Halls. Future studies must concentrate on measurements of wind velocity and direction and monitoring atmospheric pressure to test the model of airflow and speleoclimate zones of Santana Cave.
In Cristo Hall, the thermal amplitude was up to $1.1^{\circ} \mathrm{C}$ when tourists were present. In Encontro Hall, this value reached $1.3^{\circ} \mathrm{C}$. At other points in the cave, all meaningful thermal variations were attributed to anthropogenic origins. Human impacts on the air temperature dissipate quickly; thus, the possibility of anthropogenically damaging the environment directly via the speleoclimate or indirectly throughout the entire cave decreases. Therefore, the management of cave tourism based on temporal factors and on the resilience of the environment was the main focus of this research. Hence, the total daily visits are no longer the basis for the carrying capacity. Instead, the time spent by visitors at critical points in the cave where cumulative impacts occur are more important.

The findings of this research showed the importance of using the tourist carrying capacity as a management tool in which the results should be flexible in order to identify the most appropriate limits. Hence, the methodology does not refer to a set volume limit for visitation but, rather, to dynamic intervals based on field test solutions. These solutions can differ depending on the seasonality of the tourism (and the associated climate), with distinct levels of tourist carrying capacities in caves according to the tourist season or to unique management goals.

Finally, from a philosophical perspective of environmental management, the results reaffirmed that managers and scientists are responsible for finding solutions to the carrying capacity issue. These results must be studied from different points of view without expecting mathematically exact answers to tourism management in most cases. The goal of allowing the maximum possible number of visitors to a cave reinforces the need for scientific practices and long-term measures that consider the responses of measurable environmental parameters to visitation as strategic thresholds to inform rational and responsible cave tourism management.

\section{REFERENCES}

Bastian F. \& Alabouvette C., 2009 - Lights and shadows on the conservation of a rock art cave: the case of Lascaux cave. International Journal of Speleology, 38: 55-60. http://dx.doi.org/10.5038/1827-806X.38.1.6

Boggiani P.C., Silva O.J., Gesicki A.L.D., Galati E., Salles L.O. \& Lima M.M.E.R, 2007 - Definição de capacidade de carga turística das cavernas do Monumento Natural Gruta do Lago Azul (Bonito, MS). Geociências, 26: 333-348.

Calaforra J.M., Fernández-Cortés A., Sánchez-Martos F., Gisbert J. \& Pulido-Bosch A., 2003 - Environmental control for determining human impact and permanent visitor capacity in a potential show cave before tourist use. Environmental Conservation, 30: 160-167. http://dx.doi.org/10.1017/S0376892903000146

Calaforra J.M., Fernández-Cortés A., Gázquez-Parra J.A. \& Novas N., 2011 - Conservando la cueva de El Soplao para El futuro: control de parámetros ambientais. In: Valsero J.J.D. (Ed.), El Soplao: Una ventana a la ciencia subterránea. El Soplao S.L., Celis: 40-43.

Cifuentes M., 1992 - Determinación de capacidad de carga turística en áreas protegidas. CATIE, Turrialba, $28 \mathrm{p}$.

Cigna A.A., 2002 - Modern trend in cave monitoring. Acta Carsologica, 31: 35-54.

Cigna A.A., 2004 - Climate of caves. In: Gunn J. (Ed.), Encyclopedia of caves and karst science. London: Taylor \& Francis, 467-475. 
Cigna A.A., 2011 - Show cave development with special references to active caves. Tourism and Karst Areas, 4: 7-16.

Cigna A.A. \& Burri E., 2000 - Development, management and economy of show caves. International Journal of Speleology, 29: 1-27.

http://dx.doi.org/10.5038/1827-806X.29.1.1

Cigna A.A. \& Forti P., 1986 - The speleogenetic role of air flow caused by convection. $1^{\text {st }}$. contribution. International Journal of Speleology, 15: 41-52. http://dx.doi.org/10.5038/1827-806X.15.1.3

Cigna A.A. \& Forti P., 2013 - Caves: the most important geotouristic feature in the world. Tourism and Karst Areas, 6: 9-26.

Conama - Conselho Nacional do Meio Ambiente, 2004 Resolução CONAMA $n^{\circ} 347$ de 10 de setembro de 2004. Diário Oficial da União, 176: 54.

Cruz Jr F.W., Burns S.J., Karmann I., Sharp W.D., Vuille M., Cardoso A.O., Ferrari J.A., Dias P.L.S. \& Viana Júnior O., 2005a - Insolation-driven changes in atmosferic circulation over the past 116,000 years in subtropical Brazil. Nature, 434: 63-66.

http://dx.doi.org/10.1038/nature03365

Cruz Jr F.W., Karmann I., Viana Júnior O., Burns S.J., Ferrari J.A., Vuille M., Sial A.N. \& Moreira M.Z., 2005b - Stable isotope study of cave percolation waters in subtropical Brazil: Implications for paleoclimate inferences from speleothems. Chemical Geology, 220: 245-262. http://dx.doi.org/10.1016/j.chemgeo.2005.04.001

De Freitas C.R., 2010 - The role and the importance of cave microclimate in the sustainable use and management of show caves. Acta Carsologica, 39: 477-489.

Delgado M., 2007 - Análise da metodologia criada por Miguel Cifuentes referente à capacidade de carga turística. Turismo em Análise, 18: 73-93.

http://dx.doi.org/10.11606/issn.1984-4867.v18i1p73-93

Faleiros F.M. \& Campanha G.A.da C., 2004 - Petrografia e microestruturas de tectonitos da zona de cisalhamento Ribeira, Vale do Ribeira, SP e PR: implicações no zoneamento metamórfico e estrutural do Supergrupo Açungui e unidades correlatas. Revista Brasileira de Geociências, 34: 419-430.

Fernández-Cortés A., Calaforra J.M., Sánchez-Martos F. \& Gisbert J., 2006a-Microclimate processes characterization of the giant geode of Pulpi (Almería, Spain): technical criteria for conservation. International Journal of Climatology, 26: 691-706. http://dx.doi.org/10.1002/joc.1269

Fernández-Cortés A., Calaforra J.M., Jiménez-Espinosa R. \& Sánchez-Martos F., 2006b - Geostatistical spatiotemporal analysis of air temperature as an aid to delineating thermal stability zones in a potential show cave: implications for environmental management. Journal of Environmental Management, 81: 371-383.

http://dx.doi.org/10.1016/j.jenvman.2005.11.011

Fundação Florestal \& Ekos Brasil, 2010 - Plano de manejo espeleológico das cavernas do Parque Estadual Turístico do Alto Ribeira. Secretaria do Meio Ambiente, São Paulo, 460 p.

Graefe A.R., Kuss F.R. \& Vaske J.J., 1990 - Visitor impact management: the planning framework. National Parks and Conservation Association, Washington, 105 p.

Guirado E., Gázquez F., Fernández-Cortés Á., Argumosa A. \& Calaforra J.M., 2014 - Cálculo de la visitabilidad maxima en cavidades turísticas mediante el método Cavix: El Soplao (Cantabria). In: Calaforra J.M. \& Durán J.J. (Eds.), I Congreso Iberoamericano y V Congreso Español sobre Cuevas Turísticas. ACTE, Aracena, 1: 199-204.

Gpme - Grupo Pierre Martin de Espeleologia., 2009 Mapa da caverna de Santana. GPME, São Paulo.

Gpme - Grupo Pierre Martin de Espeleologia., 2012 Caverna de Santana. GPME, São Paulo.
Gutjahr M.R. \& Tarifa J.R., 1993 - Critérios relacionados a compartimentação climática de bacias hidrográficas: a bacia do rio Ribeira de Iguape-SP. In: USP (Ed)., 5th Simpósio Brasileiro de Geografia Física Aplicada. São Paulo: USP, 1: 447-449.

Hamilton-Smith E., 1997 - Monitoring visitor experience and environmental conditions at Jenolan caves, New South Wales, Austrália. In: Stitt R.R. (ed)., $13^{\text {th }}$ Cave And Karst Management Symposium. NSS, Bellingham, 1: 87-91.

Hoyos M., Soler V., Cañaveras J.C., Sánchez-Moral S. \& Sanz-Rubio E., 1998 - Microclimatic characterization of a karstic cave: human impact on microenvironmental parameters of a prehistoric rock art cave (Candamo cave, Northern Spain). Environmental Geology, 33: 231-242. http:/ / dx.doi.org/10.1007/s002540050242

IGc - Instituto de Geociências da USP, 1991 - Mapa da caverna de Santana. IGc/USP, São Paulo.

Lobo H.A.S., 2008 - Capacidade de carga real (CCR) da caverna de Santana, PETAR-SP e indicações para o seu manejo turístico. Geociências, 27: 369-385.

Lobo H.A.S., 2011 - Estudo da dinâmica atmosférica subterrânea na determinação da capacidade de carga turística da caverna de Santana (PETAR, Iporanga-SP). Unesp, Rio Claro, 392 p.

Lobo H.A.S., 2013-Perfis atmosféricos da caverna Santana (PETAR, Iporanga-SP): contribuições à classificação espeleoclimática e ao manejo espeleoturístico. Revista Brasileira de Climatologia, 12: 136-154.

Lobo H.A.S., 2014 - Tourist carrying capacity of Santana cave (PETAR-SP, Brazil): a new method based on a critical atmospheric parameter. UFSCar, Sorocaba, $21 \mathrm{p}$.

Lobo H.A.S., Perinotto J.A.J. \& Poudou S., 2009 - Análise de agrupamentos aplicada à variabilidade térmica da atmosfera subterrânea: contribuição ao zoneamento ambiental microclimático de cavernas. Revista de Estudos Ambientais, 11: 22-35.

Lobo H.A.S., Perinotto J.A. de J. \& Boggiani P.C., 2010 - Tourist carrying capacity in caves: main trends and new methods in Brazil. In: Bella P. \& Gazik P. (Ed)., $6^{\text {th }}$ International Congress of International Show Caves Association. Liptovsky Mikulas: Slovak Caves Administration, 1: 108-115.

Lobo H.A.S., Trajano E., Marinho M.deA., Bichuette M.E., Scaleante J.A.B., Scaleante O.A.F., Rocha B.N. \& Laterza F.V., 2013 - Projection of tourist scenarios onto fragility maps: Framework for determination of provisional tourist carrying capacity in a Brazilian show cave. Tourism Management, 35: 234-243.

http://dx.doi.org/10.1016/j.tourman.2012.07.008

Lobo H.A.S., Perinotto J.A. de J. \& Boggiani P.C., 2014 - Monitoramento espeleoclimático do trecho turístico da caverna Santana (PETAR, SP). Mercator, 13: 227-241.

Luetscher M. \& Jeannin P.Y., 2004-Temperature distribution in karst systems: the role of air and water fluxes. Terra Nova, 16: 344-350.

http://dx.doi.org/10.1111/j.1365-3121.2004.00572.x

Mangin A., Bourges F. \& D'Hulst D., 1999 - La conservation des grottes ornées: um problème de stabilité d'un système naturel l'e exemple de la grotte préhistorique de Gargas, Pyrénées françaises). Sciences de la Terre et des Planètes, 328: 295-301.

Milanolo S. \& Gabrovšek F., 2009 - Analysis of carbon dioxide variations in the atmosphere of Srednja Bijambarska cave, Bosnia and Herzegovina. BoundaryLayer Meteorology, 131: 479-493. http://dx.doi.org/10.1007/s10546-009-9375-5

Nghi T., Lan N.T., Thai N.D., Mai D. \& Thanh D.X., 2007 Tourism carrying capacity assessment for Phong Nha-Ke Bang and Dong Hoi, Quang Binh province. VNU Journal of Science, Earth Sciences, 23: 80-87.

Pflitsch A. \& Piasecki J., 2003 - Detection of an airflow system in Niedzwiedzia (Bear) cave, Kletno, Poland. Journal of Cave and Karst Studies, 65: 160-173. 
Poulson T.L. \& White W.B., 1969 - The cave environment. Science, 165: 971-981.

http://dx.doi.org/10.1126/science.165.3897.971

Pulido-Bosch A., Martín-Rosales W., López-Chicano M., Rodríguez-Navarro C.M. \& Vallejos A., 1997 - Human impact in a tourist karstic cave (Aracena, Spain). Emvironmental Geology, 31: 142-149.

Sánchez-Moral S., Soler V., Cañaveras J.C., Sanz-Rubio E., Van Grieken R. \& Gysels K., 1999 - Inorganic deterioration affecting Altamira cave, $N$ Spain: quantitative approach to wall-corrosion (solutional etching) processes induced by visitors. The Science of the Total Environment, 243/244: 67-84. http://dx.doi.org/10.1016/S0048-9697(99)00348-4
Šebela S. \& Turk J., 2014 - Natural and anthropogenic influences on the year-round temperature dynamics of air and water in Postojna show cave, Slovenia. Tourism Management, 40: 233-243.

http://dx.doi.org/10.1016/j.tourman.2013.06.011

Song L., Wei X. \& Liang F., 2000 - The influences of cave tourism on $\mathrm{CO}_{2}$ and temperature in Bayun cave, Hebei, China. International Journal of Speleology, 29: 77-87. http://dx.doi.org/10.5038/1827-806X.29.1.4

Villar E., Bonet A., Diaz-Caneja B., Fernandez P.L., Gutierrez I., Quindos L.S., Solana J.R. \& Soto J., 1984 - Ambient temperature variations in the hall of paintings of Altamira cave due to the presence of visitors. Cave Science, 11: 99-104. 